\title{
Policing European Metropolises
}

Paul Ponsaers, Adam Edwards, Antoinette Verhage, Amadeu Recasens i Brunet ${ }^{1}$

\section{The production process of this special issue}

During the month of March 2013, some Belgian and Dutch police researchers gathered to discuss a trajectory for the study of the pluralisation of policing in European metropolises. We observed a significant amount of comparative work on different national police systems, but only a minor comparative focus on the local reality of European metropolises. According to United Nations UN Habitat, the growth of urban population was in 1970 only 37\%, while the prospective for 2030 is $60 \%{ }^{2}$. Benjamin Barber (2013) argues consequently that the future of global governance lies with cities, and the mayors who lead them. Is the concept of the metropolis becoming increasingly important to the detriment of the concept of the national state?

It was the group's understanding that in different local settings throughout Europe policing was indeed transforming, but at the same time there was also the observation that the situation in different metropolises was not systematically documented and that such a comparative project lacked basic information. Anglo-Saxon literature was to a large extent dominating the theme of pluralisation and the group members wondered if the study of plural policing in European metropolises shouldn't be build on more solid empirical ground.

The initiative group agreed upon a few starting points:

(1) a list of the biggest metropolises was drawn up to make a selection possible of these cities which were of special interest to be included in this project;

(2) each one of the initiative group contacted a scholar specializing in policing in each of these metropolises with the objective of working together on a diagnostic of the policing system in the metropolis of their choice;

(3) a common checklist was developed, taking in different points of interest we considered as important for this setup and we agreed that this list would be used by each of the participants of the project, without considering it as a straightjacket;

\footnotetext{
${ }^{1}$ Professor dr. Paul Ponsaers is senior professor emeritus at Ghent University, Faculty of Law, department Penal Law and Criminology, Belgium. Ponsaers is president of of the Flemish Centre for Policing Studies and managing editor of the quarterly "Cahiers Politiestudies". He specialises in the field of policing, on which he published several articles. He is editor of this special issue (corresp: Paul.Ponsaers@ugent.be). Prof. Dr. Adam Edwards XXX

dr. Antoinette Verhage is editor-in-chief of EJPS. She is director of the Institute for Urban Security \& Policing Studies [SVA] and postdoc researcher at Ghent University, Belgium. Professor dr. Amadeu Recasens i Brunet is a Catalan expert in security policy. He is associated Professor at the l'Escola de Criminologia de la Universitat d'Oporto (Portugal). Recasens is member of the scientific committee of GERN (Group Européen de Recherches sur les Normativités) and author of several publications on security policy.

${ }^{2}$ See: http://unhabitat.org/
} 
(4) a first outcome of the project would be presented for publication to the European Journal of Policing Studies.

Throughout this project we used a broad concept of policing to acknowledge the central argument behind the pluralisation of policing thesis, that the state police cannot act alone on complex issues of crime and civil unrest (Jones and Newburn, 2006). Rather, we wanted to concentrate on different forms of social control, present in the European metropolises. In essence we covered different domains of interest in our checklist: (1) a brief portrait of the metropolis itself; (2) the presence of (local/city) police, but also of those components of other police agencies (national/federal/provincial/regional) on the territory of the metropolis; (3) the presence of other public uniformed ('light blue') surveillance agencies (e.g. asbo's, boa's, guardians, stewards, ...); (4) the presence of (specific) public inspectorates; (5) the presence of (specific) private commercial security agencies; (6) the presence of civil non-commercial initiatives (e.g. neighbourhood watch, vigilant groups).

We started from the observation that, as a general tendency in Europe, local (municipal) police were historically embedded in metropolises, while national forces were more present in the rural environment. Our central question in this project was, as a consequence:

- "To what extent is a local police still present in European metropolises and how is this reality linked with other actors in the security field"?

Underlying questions were:

- Is there a tendency towards the steering of urban policing at other levels than the city?

- Is there a tendency towards more or less inter-dependence between different policing actors (Edwards and Hughes, 2005; Prins et al., 2012)?

- Is it possible to characterise urban policing in terms of particular state formations (e.g. authoritarian), political rationalities (e.g. neo-liberalism, social democratic) or regimes (e.g. maintenance, developmental, progressive and transformative)?

The already mentioned checklist was used as a guide for gathering comparative information, but also as short outline for analysis. We asked the authors not to use the checklist as a formal straightjacket or a questionnaire that should be completed. We encouraged them to include historical information in their articles, responding to questions as: Where do the services present on the territory of the metropolis come from? What is their actual form? To what extent and in which direction do they evolve? We didn't use a specific time frame for this historical dimension, while we were aware of the fact that this could vary according to each specific local setting. We asked each author to determine which historical information was essential to understand the actual situation in his specific metropolis.

This special issue represents the culmination of this work to date on a venture entitled, 'The Policing European Metropolises Project (PEMP)', which we intend to develop further.. We have underestimated the language issue during this process. Too evidently English is considered to be the Esperanto of Europe, while often each specific historical and geographical reality in Europe has its own expressions and connotations, which don't translate easily in English. This is not only a matter of 
language, but also of meaning. In this respect, the social science of European policing is fundamentally hindered by this language obstacle. Each of the contributors in this issue made a tremendous effort to find their way through this translation process and provide the reader with a readable article, being as faithful as possible to the specific reality of the particular metropolis they have studied.

All the authors are grateful for the constructive criticism of the reviewers of their contributions, which have made a significant contribution to the final draft of the special issue. Nevertheless, it has been a challenging task to relate the conceptual as well as societal differences in thinking about policing in different European localities. Whether a common conceptual framework for comparison can be agreed will be a key question for the next phase of the PEMP. The first phase of contributions represented in this special issue provide more of an agenda setting role in identifying tendencies toward convergence and divergence in both the conceptualisation and experience of urban policing. To this end, the first phase of the Project is best described as inductive, providing the foundation for a common theory-building endeavour (see section 3 , below).

\section{Some trends in European Metropolises today}

The transversal reading of the papers included contributes to a better understanding of what is happening within different European metropolises. With regard to policing, each metropolis has its own organization of policing tasks. Metropolises are specific examples of policing organization, with specialist demands, that are often leading to very tailor-made configurations of policing. Still, in every case, the way in which police constellations are organized, are to a very large extent linked to policing history in a specific country and the political choices that were made in history and today. The papers show that who controls the police, also controls policy, and decides on important policing issues.

\section{Police organisations}

Berlin is policed by the Berlin State Police and the central forces of BKA and Bundespolizei. Paris is policed by the police services of the Paris Prefecture of Police (PP) and the municipal police force (in a secondary manner, aimed at prevention). London is policed by two organisations: the City of London Police (financial markets) and the Metropolitan Police Service (MPS). Barcelona is policed by the MME (Mossos d'Esquadra), the Catalan police - an armed force of civil nature -, and municipal police forces (the latter being headed by the mayor, though they have a limited function that is mainly aimed at public security and urban traffic), whereas state police plays a minimal role in policing the city. Sofia has only one National police force (one force, one type).

\section{Police authority}

In general, the mayor has the most elaborate authority when it comes to policing the metropolises (Verhage \& Ponsaers, 2014). However, in two metropolises, this is not the case: in Paris, and in Sofia. In both cases, the mayors have some say in administrative aspects, but not with regard to the police tasks and activities. While in London and Berlin, the mayor has a large impact on policing matters (in view of policy, planning and management; in London the elected Police and Crime Commissioner is the Mayor, while in Berlin the mayor is both prime minister of the state and the mayor of the city). 
Barcelona takes up a different place in this list, as they are the authorities of their own local police forces, but these local police forces have limited powers. In Sofia and Paris, the role of the mayor with regard to policing is relatively limited, as in Sofia there is only one national police force (though the mayor does have a number of indirect instruments at his disposal that allow for some steering on policing matters), and in Paris, the role of the Paris Prefect of Police is overshadowing the mayor's possibilities to take up authority on policing matters.

\section{Complexity}

Public-private policing is a reality in every metropolis. Private security has emerged in each city, though its presence differs dramatically. In Sofia, for example, private security has taken up the role of the (non-existing) municipal police, as the mayor is allowed to hire private security for every tasks he or she deems necessary. As the mayor cannot dispose of a local police force that can tackle local problems, the private sector is the solution for a mayor when he wants to have patrols carried out or checks undertaken. In Paris, where the mayor's authority in this field is also limited, this picture is not so clear, as the Public Prosecutor takes up the role of local authority, and the national police play a key role in street policing in this city. In London, Berlin and Barcelona, authors make note of the presence of private security, in malls, in shopping centres, as guards etc., but the complementariness is less distinct. Professionalization of private security has improved in the majority of the metropolises in response to increased regulation and control of commercial security.

To add to the complexity, a number of authors also refer to civil servants that are working in relation to policing. The Berlin case presents 'Ordnungsamten' in charge of parking spaces and parking violations. In Paris, this task is carried out by Agents de Surveillance [ASP], a unique body in France. In Barcelona, a municipal service (Barcelona de Serveis Municipals) is dedicated to control infractions to parking regulations. This parking-task is a very specific task as in several metropolises a particular function was designed for this activity. This function is mostly not armed, but does wear uniforms and carries out administrative controls.

\section{COP}

In certain cases, Community Policing has been clearly abolished as policing strategy (e.g. Paris, since 2003). In other cases, COP is seen as an ultimate goal, that is to be accomplished, but is far off today (Sofia). In London, Barcelona and Berlin, COP is seen as the general policing strategy.

\section{Planning policing}

In general terms, we can recognize an increasing amount of planning with regard to policing tasks. In most metropolises, the police authorities are now expected to set up a security plan. In London, this was instigated by the Mayor's Office for Policing and Crime (MOPAC), which assumed responsibility for setting the strategic direction of policing in January 2012 and for formulating a Police and Crime Plan for the duration of the four year term of office served by the elected incumbent Mayor. The first Plan covers the period 2013 - 2016.. In Barcelona, local security plans were installed in 2003. In Paris, the Prefect of Police decides on security police (though it is not clear whether he can be held accountable in view of a security plan). In Berlin and Sofia on the other hand, there are planning documents on a national level, not at the local level. In Germany, an extensive planning document is 
formulated and used to hold policy-makers to account.. In Sofia, the mayor does propose a policy plan, but security is listed at the bottom of the priorities.

\section{Towards a theory concerning Policing European Metropolises}

Given the complexity of this comparative project and the problems of translating concepts and experiences across different cultures of control, its first phase has been inductive, seeking to build theoretical insight out of the empirical information and expertise about urban policing that is currently available. Drawing upon broader developments in the field of comparative urban studies it is, however, possible to identify generic tendencies that can be used to organise the comparative analysis of urban policing and facilitate a more meaningful translation of concepts and experiences. A basic distinction can be made between tendencies toward convergence in the political-economy of global and globalised cities and divergence in the ways urban authorities in particular cities adapt to processes of global change. It is suggested this literature can be productively imported into the comparative study of urban policing in Europe.

\section{Tendencies toward convergence}

Research into the emergence and consequences of 'global cities' (King, 1990a,b; Sassen, 2001) draws its inspiration from world systems theory (Wallerstein, 1974) to argue that cities and their governance cannot be treated in isolation but must be studied in terms of a 'world urban system' into which all cities are integrated. There is an asymmetry to this as some cities, those of 'global' standing, have a greater power to project their political, economic and cultural interests. These cities do the globalising, whilst others are globalised. In particular, they generate gross social inequalities within as well as between cities with significant implications for social order and, of particular interest for this special issue, for policing.

In one sense the integration of cities into a world urban system is an historic consequence of imperial projects, from the Classical epoch of the Greek and Roman city states through the era of European colonialism to the present global city of advanced capitalism (King, 1990b; Kardulias, 1999). It is argued, however, that the distinctiveness of contemporary global cities, such as London, New York and Tokyo, is their role as, "highly concentrated command points in the organisation of the world economy ... key locations for finance and for specialised service firms, which have replaced manufacturing as the leading economic sectors ... sites of production of innovations in these leading industries ... and as markets for the products and innovations produced by these leading industries' (Sassen, 2001: 3-4). The particular significance of this for policing is in the social polarisation and disorder generated by these financial command centres both within cities, between the winners and losers of finance capitalism, especially those ejected from 'core' full-time employment into the 'peripheral' casualised labour markets of the service sector, and amongst cities compelled into 'beggar thy neighbour' competition (Harvey, 1989; Boels et al., 2013).

In these terms it is possible to view urban policing as enmeshed within a global import/export trade in social inequalities, their consequences for conflict and disorder and for various policing 'solutions' (Edwards and Matthews, 1996). The latter point has been explored through the concept of 'global policing' in which it is argued the experience of policing is local at all points but the origins of policing and its problems are increasingly transnational (Bowling and Sheptycki, 2011). Within the emerging 'transnational state system' the response to urban conflict converges as policy is transferred, 
diffused and emulated through transnational policy networks. Exemplars include the export of 'public order policing', 'problem-oriented policing', 'intelligence-led policing' and 'multi-agency policing'. So, from the perspective of world urban systems theory, there are parallel processes of social and economic change across the cities integrated into this system (Sassen, 2001: 4; Verhage \& Shapland, 2013). An implication of this perspective for the Policing European Metropolises Project is the expectation of a convergence both in the problems and policy responses of urban security (Edwards et al, 2013).

\section{Tendencies toward divergence}

Others have argued that rather than parallel processes of social and economic change, there is an interplay of global and local processes. This has been expressed by the useful, if inelegant, concept of 'glocalisation' (Swyngedouw, 1997) which seeks to capture the idea that phenomena of globalisation can intensify local differences. Cities may be integrated into a world urban system but they retain the political and economic agency to adapt to and, in turn, alter the character of this integration. This idea has been particularly influential in the study of urban governance amongst those who are keen to recognise and facilitate the discretion that is available to city authorities to alter and reform, if not transform, their social and economic conditions whilst nonetheless acknowledging the structural constraints placed upon these authorities and the consequently 'bounded' character of the discretion open to them (Mollenkopf, 1994; Mouleart et al, 2007). Urban authorities can make their own history but not in conditions of their own choosing. An instance of this theoretical approach is that of urban regime analysis which characterises governing coalitions and the resources and schemes of co-operation they utilise to 'maintain', 'develop', 'progress' or 'transform' policy agendas (Stone, 2005; Mossberger and Stoker, 2001).

In the specific field of urban policing discretion might be exercised by regimes that seek to maintain criminal justice-centred agendas or develop these by augmenting them with policies of risk management including pragmatic, situational, approaches to reducing opportunities for crime and civil unrest. Alternatively, particular cities may progress the policy agenda beyond criminal justice and risk management to more restorative and reintegrative responses to crime and civil unrest. Other cities may seek to transform the agenda by prioritising social and economic policy responses to problems of policing within a broader framework of 'urban security' (Edwards and Hughes, 2012; Edwards et al, 2013). An empirical focus for comparisons that seek divergence and particularity is the role of political leadership in cities, particularly amongst elected Mayors with responsibility for setting policing strategies and the governing coalitions of which they are apart (Devroe, 2013). This is certainly an implication of contributions to the first phase of the Policing European Metropolises Project that are reported in this special issue. Of course there are other analytical foci for comparisons of policing but a particular advantage of the focus on governing coalitions is that this places an understanding of policing continuities and change in their broader political and economic environment. Given the increased interest in global policing, how do pressures for change originating outside of particular cities and beyond the immediate influence of urban authorities condition the capacity of these authorities to act? To take a contemporary concern in Europe, how are 'austere' economic policies shaping the capacity of urban authorities to maintain or develop criminal justice responses? What are the opportunities for progressive and transformative agendas? How does the different integration of European cities into a global political-economy shape problems of and for policing in these cities? What, as a consequence, can urban authorities from different European cities 
learn from each other's experience of these problems and of policing reforms? These are the key questions provoked by the inductive first phase of the project which we intend to pursue in its second phase.

\section{The future of the project}

It is our intention to develop the Policing European Metropolises Project further in the future. There is still a lot of work to be done.

In the first place we have the objective of deepening discussion on methodological and theoretical issues in the comparison of urban policing, including a panel at the $14^{\text {th }}$ annual conference of the European Society of Criminology in Prague, under the umbrella of the Policing Working Group in September 2014. This issue will provide the basis for debate and, it is hoped, the grounds for further research on this topic.

Furthermore, we are preparing a new issue for a Dutch journal (Orde van de Dag), focussing on other important European metropolises (Rome, Amsterdam and Budapest) and broadening the empirical basis for analysis. This issue will be published in December 2014.

Other initiatives will follow later on. If interested, researchers can participate in our endeavour. Please contact us in this respect ${ }^{3}$. In the meanwhile, we hope that this issue challenges every reader and inspires future projects. Indeed, there is still a lot of work to be done on the Policing European Metropolises Project. But, as always, there has to be a starting point. It was this point we have marked in this EJPS issue.

\section{References}

Barber, B. (2013) If Mayors Ruled the World: Dysfunctional Nations, Rising Cities, Yale: Yale University Press.

Boels, D., Verhage, A., Ponsaers, P. (2013), The Informal Economy in Europe, In Body-Gendrot, S., Hough, M., Kerezsi, K., Lévy, R., Snacken, S. (Eds.), The Routledge Handbook of European Criminology, London and New York: Routledge, 204-221.

Bowling, B., Sheptycki, J. (2012) Global Policing, London: Sage.

Devroe, E. (2013) 'Local political leadership and the governance of urban security in Belgium and the Netherlands', in European Journal of Criminology, Vol. 10, 3, 314-325.

Edwards, A. and Matthews, R. (1996) 'Reflections on Recent Developments in "Social Control"', in W. Hammerschick et al (eds) Jahrbuck fur Rechts und Kriminalsoziologie, 1995, Baden Baden: Nomos.

Edwards, A. and Hughes, G. (2005) 'Comparing the Governance of Safety in Europe: A Geo-Historical Approach', Theoretical Criminology, 9/3: 345-363

\footnotetext{
3 paul.ponsaers@ugent.be; edwardsa2@cardiff.ac.uk; antoinette.verhage@ugent.be, arecasensb@gmail.com
} 
Edwards, A. and Hughes, G. (2012) 'Public Safety Regimes: Negotiated orders and political analysis in criminology', Criminology and Criminal Justice, 12(4): 433-58.

Edwards, A., Hughes, G. and Lord, N. (2013) 'Urban security in Europe: translating a concept in public criminology', European Journal of Criminology, 2013, 10(3): 260-83

Harvey, D. (1989) The Condition of Postmodernity: An Inquiry into the Origins of Cultural Change, Oxford: Basil Blackwell.

Jones, T. and Newburn, T. (Eds.) (2006) Plural Policing: a comparative perspective, London: Routledge.

Kardulias, P.N. (1999) (Ed) World-Systems Theory in Practice: Leadership, Production and Exchange, Oxford: Rowman and Littlefield Publishers, Inc.

King, A.D. (1990a) Global Cities: Post-Imperialism and the Internationalization of London, London: Routledge.

King, A. D. (1990b) Urbanism, Colonialism, and the World-Economy: Cultural and Spatial Foundations of the World Urban System, London: Routledge.

Mollenkopf, J. H. (1994) 'How to study urban political power', in J. H. Mollenkopf, (1994), a Pheonix from the Ashes: The Rise and Fall of the Koch Coalition in New York City Politics, Princeton: Princeton University Press.

Mossberger, K. and Stoker, G. (2001) The evolution of urban regime theory: The challenge of conceptualization. Urban Affairs Review 57: 45-52.

Mouleart, F., Martinelli, F., Gonzalez, S. and Swyngedouw, E., (2007) 'Introduction: Social innovation and governance in European cities: Urban development between path dependency and radial innovation', European Urban and Regional Studies 14(3): 195-208.

Prins, R.S., Cachet, A., Ponsaers, P. \& Hughes, G. (2012). Fragmentation and Interconnection in Public Safety Governance in the Netherlands, Belgium and England. In M. Fenger \& V. Bekkers (Eds.), Beyond Fragmentation and Interconnectivity, Amsterdam: IOS Press, 19-43.

Sassen, S. (2001) The Global City: New York, London, Tokyo, $2^{\text {nd }}$ Ed., Princeton: Princeton University Press.

Stone, C. (2005) 'Looking back to look forward: Reflections on urban regime analysis', Urban Affairs Review 40(3): 309-341.

Swyngedouw, E. (1997) 'Neigher Global Nor Local: "Glocalization" and the Politics of Scale', in E. Swyngedouw (Ed.) Spaces of Globalization: Reasserting the Power of the Local, London: Longman.

Verhage, A. and Shapland, J. (2013), Getting by or Getting Rich, or Simply Looking for a Better Life? The Informal Economy in Times of Economic Crisis. In: Saitta, P., Shapland, J., Verhage, A., (eds), (2013), Getting by or Getting Rich? The Formal, Informal and Criminal Economy in a Globalized World. The Hague: Eleven publishers, 389-404. 
Verhage, A., Ponsaers, P. (2014). Impacts of Community Oriented Policing, In Bruinsma, G., Weisburd, D. (Eds.), Encyclopedia of Criminology and Criminal Justice (ECCJ), New York: Springer, 2430-2435.

Wallerstein, I. (1974) The Modern World System, London: Academic Press. 